NBER WORKING PAPER SERIES

\title{
THE ANATOMY OF A RESIDENTIAL MORTGAGE CRISIS: A LOOK BACK TO THE 1930S
}

\author{
Kenneth A. Snowden \\ Working Paper 16244 \\ http://www.nber.org/papers/w16244
NATIONAL BUREAU OF ECONOMIC RESEARCH
1050 Massachusetts Avenue
Cambridge, MA 02138
July 2010

This paper has benefited from the comments of participants at the Panic of 2008 conference held at George Washington Law School. The views expressed herein are those of the author and do not necessarily reflect the views of the National Bureau of Economic Research.

NBER working papers are circulated for discussion and comment purposes. They have not been peerreviewed or been subject to the review by the NBER Board of Directors that accompanies official NBER publications.

(C) 2010 by Kenneth A. Snowden. All rights reserved. Short sections of text, not to exceed two paragraphs, may be quoted without explicit permission provided that full credit, including $\odot$ notice, is given to the source. 
The Anatomy of a Residential Mortgage Crisis: A Look Back to the 1930s

Kenneth A. Snowden

NBER Working Paper No. 16244

July 2010

JEL No. E32,G01,G18,G21,N1,N12,N62,R51

\begin{abstract}
$\underline{\text { ABSTRACT }}$
Looking back to the 1930s provides the opportunity to examine one severe mortgage crisis as we live through another. This paper examines the development of the residential mortgage market during the 1920s, the institutional disruptions that occurred in the 1930s and the policy response of federal and state governments. The crisis reshaped the structure and development of the residential mortgage market and led to a postwar system in which portfolio lenders dominated both local and interregional markets. Some pre-1930 innovations - mortgage insurance and high-leverage, affordable loans-were written into federal programs and became part of the new system. But early experiments and proposals for securitization did not survive the 1930s and the implementation of this innovation was delayed for forty years.
\end{abstract}

Kenneth A. Snowden

Bryan School of Business and Economics

P.O. Box 26165

University of North Carolina at Greensboro

Greensboro, NC 27402

and NBER

snowden@uncg.edu 


\section{The Anatomy of a Residential Mortgage Crisis: A Look Back to the 1930s}

\section{Introduction}

The residential mortgage crisis that triggered the Panic of 2008 is more severe, in terms of rates of foreclosure and decreases in home prices and residential wealth, than any since the Great Depression. We should look back to the 1930s for more than benchmarks of misery, however, since it provides an opportunity to examine the origins, impacts and consequences of one severe mortgage crisis as we live through another. In this paper I identify four elements that shaped the 1930s crisis and define its long-run impact on the nation's mortgage market:

1) The crisis was preceded by a decade during which the nation's residential mortgage debt grew at an unusually rapid pace while financial innovation reshaped the mortgage market itself. Three innovations of the 1920s figure prominently-high-leverage, affordable home mortgage loans, private mortgage insurance and two early forms of securitization.

2) Each of the intermediaries that brought innovations to the market in the 1920s suffered prolonged liquidations during the 1930s. These complex processes were publicly-managed but not publicly-financed.

3) Federal emergency measures, including a publicly-financed "bad bank" (the HOLC), strengthened institutional portfolio lenders while the innovators of the 1920s were liquidating. Additional regulatory change created institutional structures within which these portfolio lenders dominated the residential mortgage debt for the next four decades.

4) Proposals were offered to incorporate each of the innovations of the 1920s into new federal programs. One effort-for high-leverage, insured mortgages-succeeded in the form of the FHA loan program; the other-for a publicly-sponsored securitization structure - did not. As a result, securitization in the residential market was delayed for four decades and then took on a fundamentally different institutional structure. 
The paper focuses on how innovation, institutional disruptions and policy responses combined to shape events between 1920 and 1940, but these details raise broader questions concerning the causes and consequences of mortgage crises. ${ }^{1}$ These issues are examined in the conclusion of the paper where events in the 1930s are connected to developments in the mortgage market after 1950. In anticipation of that discussion, as well as to provide context for the discussion of this historical episode, Figures 1 and 2 provide a long view of the magnitude and impacts of the mortgage crisis of the 1930s.

The 1930s episode was the worst in a series of booms and busts that shaped the development of the mortgage market in the U.S. during the nineteenth and early twentieth centuries. ${ }^{2}$ The 1930 s crisis was also the last crisis in this series because policy responded in a way that favored stability over innovation. To illustrate that development, Figure 1 provides a century-long view of residential building starts and decadal growth rates in inflation-adjusted mortgage debt. ${ }^{3}$ The volume of inflation-adjusted nonfarm residential debt tripled in nominal terms between 1921 and 1929 (from \$9 to \$30 billion) and also grew faster in inflation-adjusted terms than during any other decade during the twentieth century. The expansion of mortgage debt even outpaced the well-known residential construction boom of the 1920s as the ratio of debt to residential wealth doubled from 14 to nearly 30 percent and the rate of nonfarm

\footnotetext{
${ }^{1}$ Wheelock (2008) provides a detailed account of the housing and mortgage crisis of the 1930s and the federal response to it with a particular focus on mortgage distress.

${ }^{2}$ See Snowden $(1995,2003,2007)$ for accounts of failed innovations in the farm, commercial and residential mortgage markets in the 1870s and 1890s. For the antebellum period see Sparks (1932, Chapter VI) describes failed attempts by state governments to establish real estate mortgage banks.

${ }^{3}$ Building starts include both single- and multi-family construction. The series for mortgage debt shows for each year the percentage change in the volume of residential mortgage relative to ten years earlier; this measures changes in the growth of the absolute size of the market.
} 
FIGURE 1

Building Starts \& Decadal Change in CPI-Deflated Mortgage Debt, 1890-2008

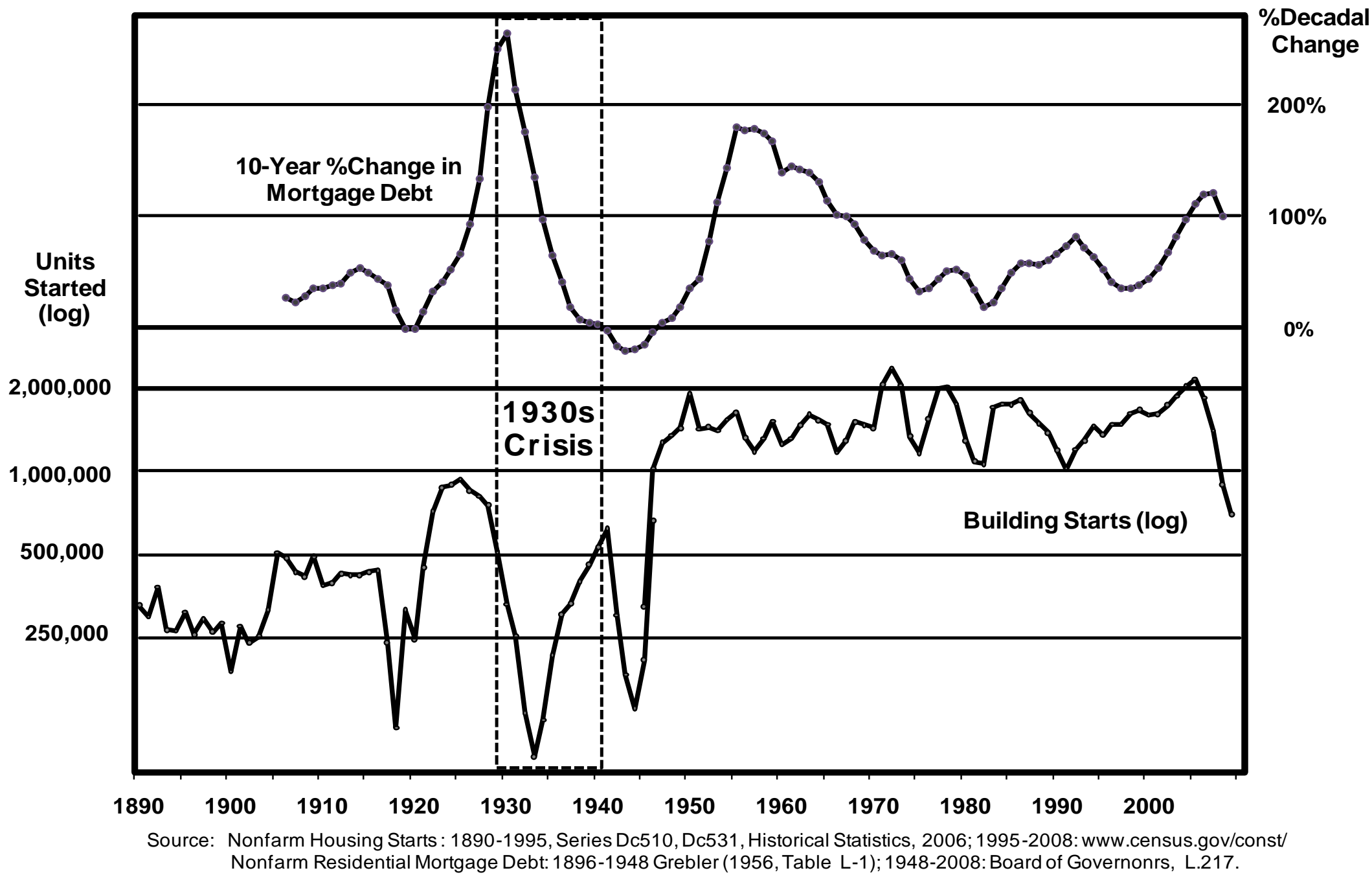


homeownership jumped from 41 to 46 percent. ${ }^{4}$ The growth in residential mortgage debt stopped suddenly in 1930 and remained virtually constant in inflation-adjusted terms across the entire 1930s while the more visible manifestations of the mortgage crisis unfolded —a total collapse in homebuilding activity and a complete reversal of the gains that were made in homeownership during the 1920s.

After the disruptions of the 1930s and World War II, the residential housing sector went through an unusual two-decade period during which mortgage debt expanded nearly as rapidly as in the 1920s, rates of home ownership surged to modern levels and homebuilding activity sustained a high level with relatively low volatility—all without reversals or crisis. The landscape changed in 1970 and for the next quarter-century inflation-adjusted mortgage debt grew modestly by historical standards and homebuilding activity remained at postwar levelsalthough with increased volatility. After 1995, however, the residential housing sector returned to the pattern we had not seen since the 1920s and 1930s — severe disruptions in the mortgage market and homebuilding activity that followed an unusually rapid expansion in both. ${ }^{5}$

Figure 2 provides a long-run view of changes in the institutional structure of the residential mortgage market over the same period. Non-institutional investors played an important role in the 1920s and two types of mortgage-backed securities appeared during that decade to serve this segment of the market. The 1930s crisis shows up in Figure 2 in two ways - the gradual but complete disappearance of private mortgage-backed securities and the

\footnotetext{
${ }^{4}$ Homeownership increased more during the 1920s than between 1890 and 1920 (37 to 41 percent). Grebler $(1956,168)$ presents estimates of mortgage debt and residential wealth for the pre-1950 era. ${ }^{5}$ For purposes of comparison, nominal GDP, mortgage debt and residential wealth were, respectively, $\$ 91.2, \$ 30$ and $\$ 79$ billion in 1930 - and $\$ 12.4, \$ 10.2$ and $\$ 16.4$ trillion in 2005. The ratio of mortgage debt to wealth in residential structures, therefore, was .38 in 1930 and .61 in 2005 while the debt to GDP ratio was .33 in 1930 and .81 in 2005 (Grebler, 1956, Table D-1 and L-6; Board of Governors, Table L.217; BEA Table 1.1.5; and BEA Fixed Asset Table 5.1).
} 
FIGURE 2

Shares of Nonfarm Residential Mortgage Debt, 1896-2007

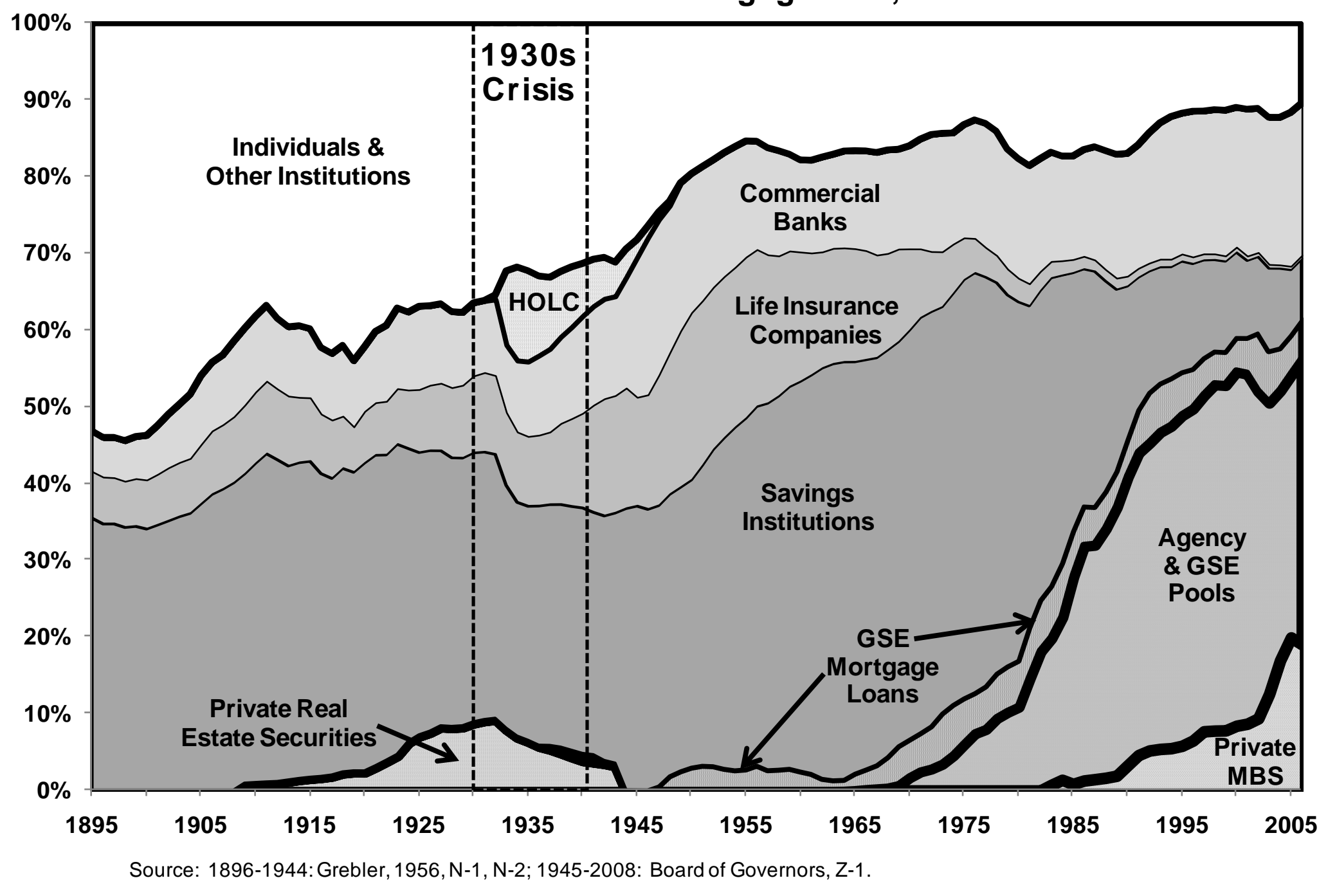


large impact of the Home Owners' Loan Corporation (HOLC) that served as a publiclysponsored "bad bank" by buying delinquent mortgages off the balance sheets of major institutional portfolio lenders. A third important institutional development during the 1930s plays a central role in the narrative below but is hidden within the "savings institutions" aggregate of Figure 2-during the crisis the traditional Building \& Loan industry was transformed into its modern Savings \& Loan form.

The long-run changes in the institutional structure of the residential mortgage market that followed the crisis of the 1930s are also clearly shown in Figure 2. The portfolio lenders that survived the crisis—commercial banks, life insurance companies, Savings \& Loans and mutual savings banks — dominated the residential mortgage market for two decades after World War II as mortgage debt, homebuilding and homeownership all increased rapidly without innovation or crisis. But fault lines began to show up after 1970 in the Depression-era mortgage structure as securitization, innovation and instability all reappeared. In the conclusion of the paper I explain how an understanding of the 1930s mortgage crisis provides perspective on these broad institutional developments after 1950 and the mortgage crisis of 2008.

\section{The Residential Mortgage Market in the 1920s}

Four intermediaries — commercial banks, life insurance companies, Building \& Loans (B\&Ls) and mutual savings banks - were the most important institutional lenders in the urban mortgage market in 1920. The first three were active in the markets for single-family, multifamily and commercial mortgages, but in different geographic areas. Mutual savings banks operated almost exclusively in New England and urban areas of the Mid-Atlantic region, while commercial banks had their largest impact in the East North Central, Mountain and Pacific regions (Morton, 1956, 
42). The headquarters of life insurance companies were geographically concentrated, but these large intermediaries lent in all regions of the country through interregional mortgage lending networks they had been developing beginning in the 1870s (Snowden, 1995). B\&Ls, in contrast to the others, specialized in home mortgage lending and had significant presence as local mortgage lenders in virtually all areas of the country.

Despite the presence of financial intermediaries, the residential mortgage market in 1920 was institutionally immature relative to modern standards. Non-institutional investors held more than 40 percent of outstanding residential mortgage debt, for example, so that large segments of the market were poorly served by intermediaries. Mortgages were also not used to finance modern levels of homeownership - only 41 percent of the nation's nonfarm housing units were owner-occupied in 1920, and only 40 percent of these properties were mortgaged. Terms on home mortgages were also less liberal: loans were typically written for no more than 50 percent of property value, were structured as straight or partially-amortized balloon loans, were restricted to maturities of 3 to 5 years, and were typically renewed one or more times before being fully repaid (Morton, 1956, 21-2). ${ }^{6}$ Finally, local supplies of mortgage credit were constrained by mortgage lending restrictions on National Banks while interregional urban mortgage lending was undertaken by only a few, large life insurance companies and private mortgage companies. ${ }^{7,8}$

\footnotetext{
${ }^{6}$ Morton $(1956,150-5)$ documents contract terms on loans written in the 1920 s by different institutions. Building \& Loans were an exception to the generalization - they offered loans up to two-thirds of the property's value with full amortization over an eleven- or twelve-year horizon.

${ }^{7}$ National banks were allowed to hold urban mortgages in 1916, but only loans with maturities of one year or less until 1927. The size of their mortgage portfolios was also limited to one-half of time deposits (Behrens, 1952, 17-21).

${ }^{8}$ Davis (1965) explains the development of interregional lending channels in the late nineteenth century as a response to capital market segmentation; Snowden $(1987,1988)$ shows the segmentation was particularly severe in the residential mortgage market. Morton (1956, 21-2) and Gray and Terborgh $(1929,14)$ show that regional disparity in mortgage rates persisted into the 1920s.
} 
The institutional gaps and rigidities that were at work in both local and interregional mortgage markets in 1920 created opportunities for change and innovation during the great mortgage expansion of the 1920s. Life insurance companies, mutual savings banks and commercial banks met the challenge by more than tripling their combined holdings of residential mortgages. ${ }^{9}$ But their combined $\$ 6.6$ billion in new investment represented only one-third of the total expansion of residential mortgage debt during the 1920s — the bulk was funded by B\&Ls ( $\$ 4.3$ billion) and non-institutional investors (more than $\$ 8$ billion). The remainder of this section examines the innovations that transformed these two components of the mortgage market.

\subsection{Building \& Loans}

The pre-Depression Building \& Loan association was a different type of intermediary than the modern Savings \& Loan (S\&L). The typical B\&L was a small, local and undiversified mutual fund into which members contributed weekly or monthly dues; the pooled dues were then lent to members who chose to purchase new or existing homes. The interest payments and fees on these loans, net of expenses and loan losses, were returned to the members as dividends. The B\&L model spread slowly for five decades after the first association was founded in the 1830 s, but during the "B\&L Movement" of the 1880s more than five thousand new associations were organized and B\&Ls became a significant source of local home mortgage credit in all regions and in cities of all sizes (Snowden, 1997). By 1920 B\&Ls remained an elastic source of

\footnotetext{
${ }^{9}$ Mutual savings banks doubled investment in residential mortgages during the 1920s but their share of residential debt decreased from 19 to 15 percent because the mortgage market expanded even more rapidly (Lintner, 1948, 218; Grebler, 1956, 472). Life insurance companies and commercial banks increased market shares during the 1920 s by quintupling and trebling their residential mortgage portfolio in only nine years (Saulnier, 1950, 13; Grebler et al, 1956, 466-8).
} 
intermediated local mortgage credit and active innovators in the design of home mortgage contracts.

State law made it much easier to incorporate a new B\&L than to charter a regulated depository institution (Snowden, 1997). As a result the industry grew during the 1920s not only by attracting new customers (from 4 to 12 million members) and assets (from $\$ 2.5$ to $\$ 8$ billion), but also by increasing in number-from some 8000 in 1919 to nearly 13000 at the peak in 1927 (Bodfish, 1931, 136). The low barriers to entry allowed B\&Ls to pursue two types of market opportunities during the 1920s. First, the industry responded quickly to the regional shift of population and homebuilding described earlier-associations, membership and assets grew much faster in southern and western markets than in the rest of the nation so that the relative importance of B\&Ls was remarkably similar in all regions by 1930 (Snowden, 2003, 169). A second more worrisome trend during the decade was the creation of associations by developers and builders for the specific purpose of financing their own suburban residential building projects (Clark, 1925, 90; Riegel, 1927, 36; Herman, 1969, 820). B\&Ls had always been organized and managed by networks of real estate professionals and builders, but regulators in Pennsylvania, Ohio, and Wisconsin documented abuses within builder-dominated B\&Ls during the 1920s that suggested conflicts of interest within the industry were becoming a greater problem (Snowden, 1997; Herman, 1969, 820). ${ }^{10}$

B\&Ls were the only lender to write amortized, long-term mortgages in the late nineteenth century, and became leaders in developing affordable, low-down payment loans during the 1920s. One of these products was called the "Philadelphia Plan." Under this arrangement the

\footnotetext{
${ }^{10}$ Piquet (1931) reports that 14 percent of the directors and 12 percent of the presidents in New Jersey B\&Ls were builders.
} 
B\&L issued a second, amortized mortgage for 30 percent of the property's value after the borrower had secured a first loan from a bank, insurance company or mortgage company for 50 percent of the property value (Loucks, 1929). The plan was affordable because the borrower paid interest only on the first, straight mortgage while the second loan was repaid according to the typical B\&L amortization schedule — at that point the borrower could refinance the straight loan as a regular, amortized B\&L mortgage loan. There was concern expressed within the industry that offering such terms placed the borrower, and the B\&L, at greater risk of default and failure. But the discussion did not prevent a variant of the Philadelphia Plan —-the "split-loan" where the B\&L held both the first and second mortgage — from being widely used during the 1920s (Loucks, 1929, 1-3, 50-61; Clark and Chase, 1925, 192-8). ${ }^{11}$

The innovations paid off for the B\&Ls - by the end of the 1920s they wrote more mortgage debt on one-to-four-family homes each year than life insurance companies, commercial banks and mutual savings banks combined (Grebler, 1956, 489). This growth was accompanied by increasing heterogeneity within the industry, however, that shaped how the industry would be affected and transformed by the impending mortgage crisis. Differences in the size, structure, and mission of individual associations polarized the B\&L industry into two groups: small, traditional B\&Ls that were managed on a part-time basis by real estate professionals and large, permanent plan associations that B\&L professionals operated as fulltime businesses. The first group took the lead in introducing the innovations discussed above, while the latter group dominated the industry's trade group - the U.S. Building \& Loan League (USBLL) - and criticized the conflicts and increased risks that were associated with these

\footnotetext{
${ }^{11}$ Gries and Ford $(1932,88)$ report that in 1928 B\&Ls in Philadelphia held a total of $\$ 721$ million of real estate loans of which $\$ 455$ million were second mortgages.
} 
innovations. So although B\&Ls were the nation's dominant home mortgage lenders in 1929, the B\&L industry was moving in two different directions on the eve of the mortgage crisis. ${ }^{12}$

\subsection{Guaranteed Mortgages, Participation Certificates and Real Estate Bonds}

The importance of non-institutional investors made the 1920s a welcoming environment for innovations that repackaged urban mortgage loans into attractive financial instruments for individual investors. Two groups of institutions - mortgage guarantee companies and real estate bond houses — were leaders in these developments and by 1930 they had together marketed between $\$ 6$ and $\$ 10$ billion of the total $\$ 44$ billion of outstanding nonfarm mortgage debt. ${ }^{13}$ Most of these securities financed commercial property development, but $\$ 2.5$ billion was issued against single and multifamily residential mortgages (Grebler, 1956, 446). These innovations were introduced in most major urban markets but had their greatest impact in the New York and Chicago metropolitan areas.

Mortgage guarantee companies actually brought two innovations to the marketmortgage insurance and participation certificates that were issued on mortgage collateral. ${ }^{14}$ The private mortgage insurance component first appeared in urban New York markets around the turn of the century when title insurance companies were given the authority to write policies not only against defects in land titles, but also on the payments due on bonds and mortgages (Alger,

\footnotetext{
${ }^{12}$ The small, serial plan B\&L associations were concentrated in Pennsylvania, Illinois and New Jersey while the larger permanent plan associations were concentrated in Ohio and New York (Snowden, 2003, 179-81).

${ }^{13}$ Goldsmith (1955, R-41) estimates that $\$ 6.5$ billion of nonfarm real estate securities were outstanding in 1931; while Halliburton $(1939,5)$ estimates a range between $\$ 6$ and $\$ 10$ billion.

${ }^{14}$ Snowden (1995) describes a similar attempt to issue mortgage-backed debentures by western farm mortgage companies in the 1880s. These programs were loosely modeled on European-style mortgage bonds, but they all failed.
} 
1934). At first these companies offered policies to investors who had originated their own mortgages or who had purchased loans from independent mortgage companies. Some guarantee companies began to combine mortgage banking functions with insurance in the 1910s by originating, selling and servicing insured commercial and residential mortgage loans. By 1921 only twelve companies in New York were active in this business, but by 1930 some fifty companies in the state had written insurance on $\$ 3$ billion of mortgages that they originated and marketed.

Two-thirds of these insured mortgages were sold as whole loans to investors, but by the end of the decade nearly $\$ 1$ billion of the insured mortgages had been placed in trust accounts against which the companies issued collateral trust certificates of participation (Chamberlain, 1927, 455). Some certificates were issued against single large mortgages, while "group certificates" were issued against pools of mortgage loans. In either case the certificates were pass-through securities written on the cash-flows generated by insured mortgages - a familiar mechanism in the modern mortgage market.

The real estate bond movement of the 1920s used a different form of securitization to finance the construction of large commercial and multifamily residential projects in major urban centers. The organizers of these ventures invested equity in corporations that were created to own specific buildings or developments; the corporation would then use a first mortgage on the property, and a lien against its net income, to secure partially amortized bonds in denominations of $\$ 100$, $\$ 500$ and $\$ 1000$ (Koester, 1939, 50; Fisher 1951, 30). ${ }^{15}$ Single-property real estate bonds were marketed on a modest scale before and during World War I, but generally only on completed properties after banks loans had been used to finance construction. By the mid-1920s, however, real

\footnotetext{
${ }^{15}$ Koester $(1939,50)$ reports that small numbers of real estate securities in Chicago used leasehold bonds rather than mortgage bonds as security, and were organized as trusts.
} 
estate bonds were issued even before construction had been completed (Chamberlain and Edwards, 1927, 444-6).

The intermediary most responsible for popularizing this innovation was the specialized real estate bond house. ${ }^{16}$ The strength and reputation of these underwriters was critical to the marketability of real estate bonds even though they accepted no legal liability for the payment of interest or principal (Gray and Terborgh, 1929, 25). The houses promised, however, to repurchase at a small discount the securities they had marketed. This policy not only protected investors against credit losses, it also provided liquidity since attempts to establish an active secondary market for real estate bonds were generally unsuccessful (Miller, 1930).

The market for single-property real estate bonds grew rapidly during the 1920s, but estimates of its size vary widely. The most conservative places outstanding issues at slightly more than $\$ 4$ billion in 1930 which represented 14 percent of total nonfarm mortgage debt and 11 percent of the total corporate debt issued between 1921 and 1930 (Clark, 1933, 66; Johnson, 1939, 45). Bonds on properties in New York and Chicago dominated the market, and one-third of all securities were issued against office buildings (Johnson, 1939, 307). Residential properties — apartments and apartment-hotels — secured less than 20 percent of real estate bond issues nationwide, but nearly 50 percent of the bonds issued on Chicago property (Johnson, 1936,307; Koester, 1939, 51).

Concerns about the general quality of real estate bonds were raised in 1926 after several bond issues defaulted. More telling, perhaps, were reports of rising vacancy rates and declining rents (Halliburton, 1939, 7-8). Several state governments investigated the industry and the Attorney General of New York actually issued a warning in 1927 that real estate bond houses were over-

\footnotetext{
${ }^{16}$ Chamberlain $(1927,443)$ notes that a few investment banks were also active in the market. Halliburton (1939) provides an exhaustive account of the real estate bond house.
} 
appraising properties and improperly managing their trust accounts (Gray, 1929, 36). Soon thereafter the American Construction Council, the National Association of Real Estate Boards and the National Association of Security Commissioners adopted explicit codes for issuers of real estate bonds that were embraced by all major bond houses (Gray, 1929, 43-5). The volume of new bond issues then surged in 1928 to its second highest level in the 1920s.

\subsection{The View from the Residential Mortgage Market in 1929}

In 1929 the Brookings Institution produced an assessment of "First Mortgages in Urban Real Estate Finance" (Gray and Terborgh, 1929). The conclusions drawn in that report provide an interesting assessment of the performance of the nation's mortgage market on the eve of its crisis. The authors acknowledged concerns about risks associated with the innovations that had appeared in the 1920s but expressed no general sense of alarm. The report focused, instead, on the failure of the market to equalize mortgage rates across region. The authors noted that the activities of life insurance companies, real estate bond houses and mortgage guarantee companies had all helped the situation during the 1920 s, but concluded that they were unlikely to solve the underlying misallocation of funds on their own. The recommendation, therefore, was to establish a public, European-style central mortgage bank - similar to the Federal Farm Loan Bank that had been established in 1916 - that could pool urban mortgages made by local originators and place them behind mortgage-backed debentures that could trade in thick secondary markets at low yields. This same model would be proposed a few years later at the depth of the mortgage crisis, but was ultimately rejected. 


\section{The Crisis of the 1930s: Disruptions, Emergency Measures and a New System}

[A] tremendous surge of residential building in the [last] decade... was matched by an ever-increasing supply of homes sold on easy terms. The easy terms plan has a catch...[o]nly a small decline in prices was necessary to wipe out this equity. Unfortunately, deflationary processes are never satisfied with small declines in values. They feed upon themselves and produce results out of all proportion to their causes....[O]ur economic system has become so complex and so finely balanced that every business transaction affects vitally many other transactions. In the field of real-estate finance, particularly, we have depended so much upon credit that our whole value structure can be thrown out of balance by relatively slight shocks. When such a delicate structure is once disorganized, it is a tremendous task to get it into a position where it can again function normally. (Hoagland, 1935)

Henry Hoagland was well-positioned in 1935 to assess the state of the mortgage market because he was a member of the Federal Home Loan Bank Board that was the lead agency overseeing nearly all of the federal programs designed to ameliorate the crisis. The timing of Hoagland's somber view is as disquieting as its content- - he was writing eight years after the peak in housing construction, six years after the onset of recession, three years after the FHLB system had begun to supply liquidity to the home mortgage market and two years after the passage of New Deal emergency housing measures. ${ }^{17}$ In this section we examine the dislocations which arose during the mortgage crisis and the federal government's response to it.

Rates of nonfarm mortgage foreclosure began to escalate in the late 1920s and reached the level of a thousand per day in 1933 before falling back slowly to pre-depression levels by 1940. Estimates of nonfarm residential mortgage holdings of closed commercial banks and Building \& Loans show a similar trend —increases to $\$ 250$ million in each by 1933 followed by gradual decreases for the remainder of the decade (Grebler, 1956, 489). But the extent and

\footnotetext{
${ }^{17}$ The FHLBB oversaw the Home Owners' Loan Corporation, a new system of federally-chartered Savings \& Loan Associations, the Federal Savings \& Loan Insurance Corporation and the discounting facilities of the Federal Home Loan Banks.
} 
timing of disruptions during a mortgage crisis are not fully captured by trends in foreclosure rates or numbers of failed institutions. Foreclosures by Massachusetts mutual savings banks, for example, also peaked in 1933 and receded slowly thereafter; but the amount of foreclosed real estate held by these institutions did not peak until 1937 and represented two-thirds of their capital surplus accounts until 1940 (Lintner, 1948,272). As Hoagland emphasized, recovery from the mortgage crisis was complex, protracted and difficult.

The disruptions in the mortgage market began as the total nominal residential debt fell from $\$ 30.2$ to $\$ 25.5$ billion between 1930 and 1933 (Grebler, 1956, 466). Ninety percent of the decrease occurred in the mortgage holdings of Building \& Loans and non-institutional investors even though these two groups together held only 60 percent of the total debt in 1930. After their poor performance in the first stage of the crisis, these innovators of the 1920 s were allowed to slowly liquidate and disappear while federal policy rehabilitated other institutions.

\subsection{The Demise of B\&Ls, Guaranteed Mortgages and Real Estate Bonds}

Traditional Building \& Loan associations entered the 1930s with a unique contractual structure - called the share accumulation loan plan - that placed thousands of institutions into protracted liquidations during the crisis of the 1930s (Clark and Chase, 1925, 134-7). The B\&Ls achieved loan amortization with this plan by combining two contracts - a straight mortgage loan that required periodic interest payments and a subscription to buy shares in the association, in installments, that were equal in face value to the principal of the loan. Amortization was accomplished, therefore, through a sinking fund; after 11 or 12 years the value of the member's share account grew equal to the loan balance and the debt was cancelled. These contracts caused 
severe problems for B\&Ls during the 1930s because losses on one member's loan reduced the value of all other members' sinking fund and, therefore, increased their effective loan balances. ${ }^{18}$

Thousands of associations that operated under the share accumulation loan plan were forced to close in the early 1930s as defaults and foreclosures by some members encouraged others to stop making loan payments. But B\&Ls were protected from involuntary liquidation because they were member-owned corporations, not depository institutions (Clark and Chase, 1925, 400-1). So when faced with large demands for withdrawals a B\&L became "frozen" and operated only to liquidate its loan portfolio and real estate account on behalf of members. ${ }^{19}$ Thousands of associations found themselves in this condition during the 1930s. By 1933 some 2000 associations were frozen and the foreclosed real estate holdings of the industry represented 17 percent of industry assets (or $\$ .8$ billion). Another 3000 associations closed after 1933 and real estate still represented 12 percent of industry-wide assets in 1939. Real estate holdings were highest (22\% of assets) in the Mid-Atlantic region where the traditional serial associations were common. Conditions remained so weak in Philadelphia, Milwaukee, New Orleans and New Jersey, in fact, that the FSLIC undertook special Community Programs in 1936 "to bring about comprehensive rehabilitation of the savings and loan industry in certain localities where general weaknesses in ... structure have been apparent" (Eighth Annual Report, FHLBB, 1940, 107-10, 227-31). More than one-half of the 12000 B\&Ls that were operating in 1929 had failed by 1941 , many of them through a process of liquidation that took years to complete.

\footnotetext{
${ }^{18}$ The principal on the modern direct reduction loan, in contrast, decreases each time the borrower makes a payment of principal. A minority of B\&Ls employed the direct reduction contract in the 1920s, but most were required by state law to use the share accumulation contract (Bodfish, 1931, 203-5).

${ }^{19}$ Members in a frozen B\&L could wait for liquidation, reorganize their association into a "good" and "bad" B\&L, or liquidate shares in a secondary market at a discount (Kendall, 1962, 76-7, 144; Bodfish and Theobald, 1938, 161; Ewalt, 1962, 116-8).
} 
The mortgage guarantee companies that were concentrated in New York during the 1920s operated under the supervision of that state's Department of Insurance. These companies were subject to examination each year, but by 1932 not one major company had been closed. But the frequency and thoroughness of examinations increased after nearly all companies delayed repayment of principal to investors in 1931 (Alger, 1934, 59). Regulators continued to exercise forbearance, however, in the hope that the companies would recover.

Forbearance ended with the national bank holiday in March 1933 when state regulators ordered the mortgage guarantee companies to stop selling guarantees and distributing dividend payments. Five months later the Department of Insurance seized 18 mortgage guarantee companies for liquidation (Alger, 1934, 63). These companies together had sold \$1 billion of insured whole mortgage loans and $\$ .8$ billion of participation certificates on loans that were held in trust accounts; these certificates were held by more than 200000 investors. ${ }^{20}$ The Department of Insurance found that $\$ 1.1$ billion of guaranteed mortgages were in default and that the default rate was highest among the mortgages that had been placed behind participation certificates. In response, the state legislature eventually passed the Shackno Act and created a temporary Mortgage Commission to facilitate the liquidation process (Cramp, 1940, 1). At that point the disposition of $\$ .7$ billion of guaranteed mortgages still had to be worked out — a process that continued until the early 1940s.

The public investigation of the mortgage guarantee industry in New York revealed that companies had violated underwriting standards, substituted bad loans for performing mortgages in their mortgage pools, and maintained inadequate guarantee funds to support their insurance policies. Some of these abuses were the result of gaps in the regulatory structure and poor oversight, but there

\footnotetext{
${ }^{20}$ In describing the task facing the regulator the Moreland Commissioner noted (Alger, 1934, 2) that the assets of the guarantee companies represented more than forty times the volume of all liquidations the Department of Insurance had handled since its inception in 1859.
} 
was little appetite for reform or remediation. In 1937 the Joint Legislative Committee to Investigate the Guaranteed Mortgage Situation concluded "that the business of guaranteeing mortgages should be prohibited entirely" (New York, 1937). Private mortgage insurance was not written again in the U.S until the 1950s (Rapkin, 1967).

Real estate bond houses, unlike mortgage guarantee companies, were not publicly regulated. By 1929 market participants signaled concern about their viability, however, and the volume of newly-issued real estate bonds fell dramatically. Defaults increased in the same year and peaked on securities written on Chicago properties in 1931. By 1935 eighty percent of all outstanding real estate bonds were in default and the rate was even higher for apartment buildings in Chicago, Detroit and Cleveland (Koester, 1939, 54). ${ }^{21}$ The average recoverable value on all defaulted real estate securities during the mid-1930s was estimated to be just over 50 percent of face value.

Real estate bond houses were excoriated for the methods they used to originate bonds and sell securities, and for abusing their position as fiscal agents for the bondholders. ${ }^{22}$ Real estate bonds earned their greatest notoriety, however, when 10000 bondholders gathered in Chicago in April 1934 to protest the treatment they received after their bonds had defaulted. The uproar led the U.S. Congress, under the auspices of the Sabath Committee, to conduct an investigation in 1935 of real estate bondholders' reorganizations and to sponsor remedial legislation in amendments to the Securities and Exchange Act and the federal bankruptcy law (Halliburton, 1939, 125). These legal complications, along with the sheer size and number of defaults, led to a contentious decade of recovery and the disappearance of the single property real estate mortgage bond. ${ }^{23}$

\footnotetext{
${ }^{21}$ Johnson (1936a \& 1936b) examined the status of all real estate bonds offered between 1919 and 1931 in amounts of at least $\$ 1$ million - 1100 securities with a combined face value of $\$ 2.7$ billion

${ }^{22}$ Halliburton (1939, 43-96) provides an exhaustive account.

${ }^{23}$ Koester (1939a \& 1939b) examines the operation of the secondary real estate bond market after 1935.
} 


\subsection{Emergency Measures: the FHLB System and the HOLC}

The federal government implemented emergency measures to respond to the mortgage crisis as the protracted liquidations described above were unfolding. These programs did not save traditional B\&Ls, guaranteed mortgage companies or real estate bond houses - the goal was to relieve distress within other major institutional mortgage lenders.

Among the institutions to be assisted was the subset of B\&Ls that favored the model of a large, professionally-managed institution that their trade group, the USBLL, had been advocating for more than a decade. The mortgage crisis presented an opportunity for this segment of the industry to distance itself from the traditional B\&Ls and to do so it used the new Federal Home Loan Bank system. ${ }^{24}$ The USBLL first pressed Congress to create a federal discount bank for B\&Ls in 1919, but met with little success until Hoover supported the creation of a home loan bank in his 1928 campaign. The President finally made good on the pledge in 1932 over the objections of the B\&Ls principal competitors-commercial banks, life insurance companies and mortgage companies. Two senior USBLL executives actually helped Congress draft the Federal Home Loan Bank Act that was enacted in summer 1932 (Ewalt, 1962, 87; Bodfish and Theobald, $1938,290)^{25}$

The USBLL not only helped to draft the FHLB Act, it also supplied two League executives to the original FHLB Board and 91 out of 132 directors to the boards of the system's twelve regional banks. These facilities began to make advances to member institutions in early 1933 so that they could honor withdrawals from members and refinance the loans of distressed

\footnotetext{
${ }^{24}$ Hoover endorsed the idea of a home mortgage discounting facility at his 1931 Conference on Homebuilding and Home Ownership at which real estate professionals, planners, architects and mortgage market participants discussed policy towards construction, ownership and financing of housing. ${ }^{25}$ Life insurance companies and savings banks were eligible to join the FHLB, but few did.
} 
homeowners (Ewalt, 1962, 66). ${ }^{26}$ The same FHLB discount facilities could have been used to assist the thousands of B\&Ls that were experiencing severe distress by 1933, but only sound institutions with management and loan policies consistent with building and loan "ideals" were accepted into the system (Snowden, 2003, 195). This entry policy became a powerful tool for reshaping the industry. There were nearly 11000 B\&Ls in 1933 - many of them already frozen. Only 2086 of these had become FHLB members by December of 1933 and only 3900 (including 600 new Federal S\&Ls) joined the system over the next four years. These associations became the core of the modern S\&L industry and ended up holding 92 percent of all S\&L assets by 1950.

The Home Owners' Loan Act of June 1933 represented a second federal emergency response to the mortgage crisis. The act authorized the Home Owners' Loan Corporation to offer new loans to homeowners who were delinquent on existing mortgages. HOLC accomplished the task by opening 400 offices throughout the country and employing a staff of 20000 to process loans and appraise properties. In only three years the agency received applications from 40 percent of all residential mortgagors and wrote new loans on ten percent of the owneroccupied homes in the U.S. In doing so the HOLC implemented two underwriting standards that assisted the homeowners: 1) all HOLC loans were long-term (15 year), fully- amortized, direct reduction loans and 2) HOLC appraised each property at its "normal" market value rather than at its current market price. After approving a loan, HOLC offered to purchase the defaulted loan from the original lender under the terms its underwriters had set. The lender could refuse to sell if the loan amount approved by HOLC did not fully extinguish the borrower's obligation, but the principal on thousands of defaulted mortgage loans were written down through the HOLC underwriting process.

\footnotetext{
${ }^{26}$ During the Bank Holiday of March 1933 the new FHLB advanced $\$ 40$ million of currency to member B\&Ls - these were the only financial institutions in the nation that offered their members cash during the bank holiday (Ewalt, 1962, 66-7).
} 
In less than three years HOLC exchanged $\$ 2.7$ billion of its own bonds for delinquent mortgages that were held by mortgage lending institutions - more than $\$ .7$ billion each from B\&Ls, commercial banks and life insurance companies, and $\$ .5$ billion from individual lenders and other intermediaries. HOLC was, in essence, a publicly-financed "bad bank" for home mortgage lenders. The agency did not address the problems of frozen B\&Ls, guaranteed mortgage companies or real estate bonds, but it restored the balance sheets of major institutional lenders that would become dominant in the post-crisis residential mortgage market. The HOLC's authority to make loans expired in 1936 after which it serviced its outstanding loan portfolio until the agency was liquidated in $1951 .^{27}$

\subsection{The New System Emerges: Federal S\&Ls, FHA and FNMA}

Once the FHLB discount facility and the HOLC lending program were in operation, there was opportunity to address permanent regulatory considerations. Two issues took precedence. First, how would the USBLL use its influence within the FHLB system to reshape surviving B\&Ls into a modern, professionally-managed Savings \& Loan industry? Second, what would become of the innovations of the 1920s - high-leverage loans, mortgage insurance, participation certificates and real estate bonds - given that the intermediaries who introduced them were all liquidating? The structure of the nation's residential mortgage market was permanently transformed as these issues were resolved.

The FHLB Board was given authority in the Home Owners' Loan Act of June 1933 to establish a system of federally-chartered Savings and Loan Associations, but the legislation

\footnotetext{
${ }^{27}$ Harriss (1951) provides the definitive treatment of the HOLC. Tough (1951) assesses HOLC effectiveness upon its liquidation.
} 
provided few specific details. The USBLL recommended that the Board consider adopting its own comprehensive "Uniform Code" that had been developed in the late 1920s, and much of it was incorporated into the FHLB guidelines (Bodfish and Theobald, 1938, 516-17, 556-67; Ewalt, 1962, 80-81). Two elements of the model ensured that members of the federal S\&L industry would be structured and behave differently than traditional B\&Ls. First, federal S\&Ls offered new kinds of contracts: share savings accounts instead of membership dues and direct reduction loans to replace the fragile share accumulation loan plan. Second, federal charters erected new barriers to entry so that small, part-time associations would never again represent a competitive fringe. ${ }^{28}$

The final element of the industry's transformation-the FSLIC insurance program-was enacted in the 1934 National Housing Act. The USBLL (soon to become the U.S. Savings and Loan League) originally opposed the creation of an insurance program because of concerns with moral hazard. But the S\&L industry ultimately became convinced that it would suffer a competitive disadvantage without share account insurance because bank deposits were by then insured by the FDIC (Ewalt, 1962, 91-96). More than 20 percent of B\&Ls and S\&Ls (1450 in number) operated under Federal charters by 1941 and together they held 35 percent of the industry's assets. More than 800 of these institutions had entered the federal system by converting from their original state charters, the remaining 639 were new associations that organized as Federal S\&Ls. These institutions, along with the state-chartered associations that joined the FHLB system, comprised the heart of the S\&L industry for the next four decades.

\footnotetext{
${ }^{28}$ New federal charters could be issued only if the applicant could demonstrate that its entry would not injure an existing association. The FHLB also adopted a " 50 -mile rule" which restricted the lending activities of chartered associations to their local markets. These provisions created local S\&L monopoly markets that became a target for deregulation in the 1970s and 1980s.
} 
Title I of the National Housing Act of 1934 created the Federal Housing Administration which became a counterbalance to the USBLL-dominated FHLB Board in the formulation of federal residential mortgage policy (Ewalt, 1962, 138-44). Title II of the act, moreover, created the FHA mortgage insurance program that was designed to encourage commercial banks, competitors of S\&Ls, to increase their presence in the mortgage market. The FHA loan program itself was objectionable to the USBLL because it insured long-term, highly-levered, fullyamortized loans to stimulate housing demand. The USBLL saw this as a government subsidy for the same type of risky loan products that traditional B\&Ls had promoted in the 1920s. S\&Ls were eligible to use the FHA program, but made relatively little use of it in the post-World War II era. There was also criticism of specific terms on FHA loans - the loan limits and loan-to-value ceilings were initially thought to be too low and the insurance funding fee too high. Changes in these features soon attracted commercial banks, life insurance companies and, interestingly, mortgage companies to the program. FHA loans, and VA guaranteed loans in later years, came to play three important functions in the post-crisis residential market (Jones, 1961, 40-44; Klaman, 1959). First, federally-insured and guaranteed mortgages became the dominant instrument that was used in the interregional transfer of mortgage credit. Second, these loan programs were used to finance the activities of large merchant builders because they provided advanced commitments for permanent financing during construction. Finally, FHA financing was used extensively to finance the expansion of the multifamily housing stock. Note that builder-dominated B\&Ls, mortgage guarantee companies and the real estate bond houses performed the same three functions during the 1920s. So the FHA and VA mortgage programs helped life insurance companies, mutual savings banks and commercial banks to fund segments of the residential mortgage market that had previously been served by the failed innovations of the 1920 s. 
Title III of the National Housing Act authorized the creation of a system of privately-owned, federally-chartered National Mortgage Associations to buy and sell FHA loans from local originators. The associations were to finance their activities by issuing debenture bonds against insured loans that they held in their portfolios (Jones and Grebler 1961, 115-9). These institutions were similar in structure to the private joint-stock mortgage banks that had been created under the Federal Farm Loan Act of 1916. The idea at that time, and the intended purpose of the National Mortgage Associations, was to introduce European-style mortgage banking to the American mortgage market. The Brookings Institution advocated for a similar system in 1929, while an almost identical proposal was introduced in the New York state legislature in 1935 (Gray and Terborgh, 1929; New York, 1935). These plans, had they been adopted, would have fundamentally changed the structure of the residential mortgage market.

The New York proposal was never enacted, and by 1937 not one National Mortgage Association had been organized despite modifications to the original legislation that were designed to attract private investors (Jones, 1961, 116). In order to demonstrate the viability of the proposed system the Federal Housing Administrator authorized the Reconstruction Finance Corporation to organize a National Mortgage Association of Washington in February 1938. It was soon renamed the Federal National Mortgage Association and its first issue of \$25 million of debentures was oversubscribed by a factor of fifty. Despite the success of this experiment, the FHA announced in May that it would no longer process applications and not one privately-owned mortgage association was ever chartered under the National Housing Act. ${ }^{29}$ With the proposals for a regulated mortgage

\footnotetext{
${ }^{29}$ The New York Times, May 28, 1938 reported that applications for new NMAs increased after FNMA's successful bond offering, but that with the FHA decision "private interests planning to take advantage of this potential market... appear doomed to disappointment or at least considerable delay." Jones and Grebler $(1961,115)$ refer to the NMA proposal as a "frustrating episode."
} 
securitization system turned aside, the FNMA functioned for the next three decades as a secondary market discount facility serving institutions that originated and held federally-insured and guaranteed loans.

\section{The Legacy of the 1930s Mortgage Crisis}

By 1939 a decade of crisis, emergency measures and regulatory change had created a system of institutional portfolio lenders that would dominate the residential mortgage market for the next thirty years. The new Savings \& Loan industry served local mortgage markets and small-scale builders; commercial banks and mortgage companies used FHA and VA loans to finance large tract builders and multifamily projects; and life insurance companies and mutual savings banks dominated the interregional residential mortgage market through networks of dedicated mortgage companies. Within this structure depository financial institutions came to dominate the residential mortgage market as never before or since, regulatory boundaries limited competition among lender groups, financial innovation was deemphasized, and loan origination, servicing and credit risk management were integrated within a single institution or small networks of institutions. The structure was particularly well-suited to the massive post-WWII expansion of residential mortgage debt and successfully financed a historic surge in homebuilding and home ownership without crisis or substantial instability.

By the late 1960s, however, serious problems arose within the postwar mortgage system. The problem arose because the standard home mortgage loan that had emerged during the 1930s shifted nearly all of the risks associated with changes in interest rates on the lender-borrowers enjoyed fixed-rate long-term rates even if long-term rates increased during the term of their 
mortgage but could also refinance loans without prepayment penalties if long-term rates fell.

During the 1950s and 1960s interest rates remained low and stable and so the portfolio lenders that dominated the residential market were shielded from the risks associated with funding their mortgage portfolios. But the situation changed markedly when the level and variability of inflation and nominal interest rates increased in the 1970s; all portfolio mortgage lenders had difficulty funding mortgages profitably and the S\&Ls were particularly hard-hit by the liability-asset mismatch. As the share of residential mortgage debt held by S\&Ls, life insurance companies and mutual savings banks fell in the 1970s and especially in the 1980s, securitization once again appeared in the U.S. mortgage market but this time for different reasons and in a different form than in the $1920 \mathrm{~s}$.

The modern form of mortgage securitization in the U.S also took a different form than the system of federally-chartered, private mortgage banks that had been proposed in the National Housing Act of 1934. Modern securitization, instead, was narrowly built on one federal agency (Ginnie Mae) and the Government Sponsored Enterprises (Fannie Mae and Freddie Mac) that were carved out in 1970 from the secondary market operations of the depression-era FNMA and FHLB system. These agencies guaranteed the credit risk on pools of mortgage loans so that their cashflows could be passed-through as marketable securities. These mortgage-backed securities also passed-through the interest rate risk that had undone institutional portfolio lenders, so in the 1980s private agencies began to repackage GSE pass-throughs within structured, collateralized securities that offered different exposures to the funding and prepayment risk associated with changes in interest rates. The result was the surge in the share of mortgage debt financed by GSE pools between 1970 and 1990 that we have seen earlier in Figure 2. 
In the 1990s the boundaries in mortgage securitization shifted in two important ways. First, the GSEs began to generate profits for their stockholders by retaining large volumes of whole mortgages and pass-through securities in their own portfolio and funding these securities, and the interest rate risk they carried, at low interest rates because of their implicit federal guarantee. Second, private agencies began issuing and underwriting credit risk on their own mortgage-backed securities in order to market mortgages that the GSEs would not securitize. By 1995 forces converged to generate the third great expansion of mortgage debt in the past century, the reemergence of private-label mortgage securitization on a scale not seen since the 1920s, a relaxation of mortgage lending standards and, finally, the most severe mortgage crisis since the 1930s. 


\section{References}

Alger, George (1934), Report on the Operation, Conduct, and Management of Title and Mortgage Guarantee Corporations. New York.

Behrens, Carl F. (1952), Commercial Bank Activities in Urban Mortgage Financing. New York: National Bureau of Economic Research.

Board of Governors of the Federal Reserve System (2008), Flow of Funds Accounts of the United States, Federal Reserve Statistical Release Z.1 (December 11, 2008), Washington, D.C.

Bodfish, H. Morton (1931), History of Building and Loan in the United States, Chicago: United States Building and Loan League.

Bodfish, H. Morton and A.D. Theobald (1938), Savings and Loan Principles, New York: Prentice Hall.

Chamberlain, Edward and G. Edwards (1927), The Principles of Bond Investment, New York: Henry Holt.

Carter, Susan B., Scott S. Gartner, Michael R. Haines, Alan L. Olmstead, Richard Sutch, and Gavin Wright (eds) (2006), Historical Statistics of the United States, Earliest Times to the Present: Millennial Edition, New York: Cambridge University Press.

Clark, Horace and Frank A. Chase (1925), Elements of the Modern Building and Loan Associations, New York: Macmillan and Co.

Cramp, Ralph (1940), "Guaranteed Mortgage Companies in Review -- A program for the Future," Contemporary Law Pamphlets, Series 4, No. 6, NYU School of Law, 40 pp.

Davis, Lance (1965), "The Investment Market, 1870-1914: The Evolution of a National Market," Journal of Economic History, 25 (2), 355-93.

Ewalt, Josephine (1962), A Business Reborn, Chicago: American Savings and Loan Institute.

Federal Home Loan Bank Board, Annual Report, Washington, D.C., various years.

Fisher, Ernest M. (1951), Urban Real Estate Markets: Characteristics and Financing, New York: National Bureau of Economic Research.

Gray, John H. and George W. Terbough (1929), "First Mortgages in Urban Real Estate," The Brookings Institute Pamphlet Series, 1 (2).

Goldsmith, R. (1955), A Study of Savings, Princeton: Princeton University Press.

Grebler, Leo, D. Blank and L. Winnick (1956), Capital Formation in Residential Real Estate, Princeton: Princeton University Press.

Gries, J.M. and J. Ford (eds) (1932), President's Conference on Home Building and Home Ownership, Washington, D.C.: National Capital Press.

Halliburton, Robert A. (1939), The Real Estate Bond House. Franklin, Indiana: Indiana University. Harriss, Lowell (1951), History and Policies of the Home Owners' Loan Corporation, New York: National Bureau of Economic Research.

Herman, Edward, S. (1969), "Conflicts in the Savings and Loan Industry," in I. Friend (ed.), Study of the Saving and Loan Industry. Vol. 2, Washington, D.C.: Government Printing Office.

Hoagland, Henry (1935), "The Relation of the Work of the Federal Home Loan Bank Board to Home Security and Betterment," Proceedings of the Academy of Political Science, 16 (2), 45-52. 
Johnson, Ernest A. (1936a), "The Record of Long-term Real Estate Securities," Journal of Land and Public Utility Economics, 12 (1), 44-8.

Johnson, Ernest A. (1936b), "The Record of Long-term Real Estate Securities: By Types of Property," Journal of Land and Public Utility Economics, 12 (3), 306-9.

Jones, Oliver and Leo Grebler (1961), The Secondary Mortgage Market, Los Angeles: UCLA.

Klaman, Saul (1959), The Postwar Rise of the Mortgage Company, New York: National Bureau of Economic Research.

Kendall, Leon T. (1962), The Savings and Loan Business, Englewood Cliffs, N.J.: Prentice-Hall.

Koester, Genevieve (1939a), "Chicago Real Estate Bonds, 1919-1938: I. Corporate History," Journal of Land and Public Utility Economics, 15 (1), 49-58.

Koester, Genevieve (1939b), "Chicago Real Estate Bonds, 1919-1938: II. Market Behavior," Journal of Land and Public Utility Economics, 15 (2), 201-11.

Lintner, John. (1948), Mutual Savings Banks in the Savings and Mortgage Markets, Boston: Harvard University.

Loucks, William N, ((1929), The Philadelphia Plan of Home Financing, Research Monograph No. 2, Chicago: The Institute for Research in Land Economics \& Public Utilities.

Miller, Cyrus (1930), "An Organized Real Estate Securities Exchange," Annals of the American Academy of Political and Social Science, 148, 26-32.

Morton, Joseph (1956), Urban Mortgage Lending: Comparative Markets and Experience, Princeton: Princeton University Press.

New York State (1937), Report of the Joint Legislative Committee to Investigate the Guaranteed Mortgage Situation, Albany: J.B. Lyon Company.

New York State Mortgage Commission (1936), Recommendations as to Proposed Legislation Pursuant to Subsection 21 of Section 4 of Chapter 19 of the Laws of 1935, Albany: J.B. Lyon Company.

Piquet, Howard (1931), Building and Loan Associations in New Jersey, Princeton: Princeton University Press.

Rapkin, C. and J. Ferrari, R. Blood and G. Milgram (1967), The Private Insurance of Home Mortgage, Philadelphia: University of Pennsylvania.

Riegel, Robert and J. Russell Doubman (1927), The Building and Loan Association, New York: John Wiley \& Sons.

Robins, Kingman, (1916), The Farm Mortgage Handbook, New York: Doubleday.

Saulnier, Raymond (1950), Urban Mortgage Lending by Life Insurance Companies, New York: National Bureau of Economic Research.

Snowden, Kenneth (1988), "Mortgage Lending and American Urbanization, 1880-1890," Journal of Economic History, 48 (2), 273-285.

Snowden, Kenneth (1995), "Mortgage Securitization in the U. S.: 20th Century Developments in Historical Perspective," in M. Bordo and R. Sylla (eds), Anglo-American Financial Systems, New York: Irwin, 261-98.

Snowden, Kenneth (1995), "The Evolution of Interregional Mortgage Lending, 1870-1940: The Life Insurance-Mortgage Company Connection," in N. Lamoreaux and D. Raff (eds), Coordination and Information: Historical Perspectives on the Organization of Enterprise, Chicago: University of Chicago, 209-47. 
Snowden, Kenneth (1997), "Building and Loan Associations in the U.S: The Origins of Localization in the Residential Mortgage Market," Research in Economics, 51 (3), 22750.

Snowden, Kenneth, (2003), "The Transition from Building and Loan to Savings and Loan, 18901940”. In S. L. Engerman, P. T. Hoffman, J. L. Rosenthal, \& K. L. Sokoloff (eds), Finance, Intermediaries, and Economic Development, New York: Cambridge University Press.

Snowden, Kenneth A., (2007), "Covered Farm Mortgage Bonds in the Late Nineteenth Century U.S," unpublished working paper.

Sparks, Earl (1932), History and Theory of Agricultural Credit in the United States, New York: Thomas Y. Crowell Company.

Tough, Rosalind (1951), "The Life Cycle of the Home Owners' Loan Corporation," Land Economics, 27 (4), 324-31.

Wheelock, David (2008), "The Federal Response to Home Mortgage Distress: Lessons from the Great Depression," Federal Reserve Bank of St. Louis Review, 90 (3), 133-48. 